\title{
ASSOCIATION BETWEEN SODIUM AND FAT CONSUMPTION WITH HYPERTENSION AT ARIFIN ACHMAD GENERAL HOSPITAL IN RIAU
}

\author{
Annisa Amalia Huzaipah, Evawany Y. Aritonang, Rahayu Lubis \\ Faculty of Public Health, Universitas Sumatera Utara
}

\begin{abstract}
Background: Hypertension is a well-known risk factor for cardiovascular diseases (CVDs). Over the past century, salt has been the subject of intense scientific research related to blood pressure elevation and cardiovascular mortalities. Moderate reduction of dietary salt intake is generally an effective measure to reduce blood pressure. Earlier studies have demonstrated that higher intakes of cholesterol and saturated fat are associated with increased blood pressure. The purpose of this study was to determine the association between sodium and fat consumption with hypertension at Arifin Achmad General Hospital in Riau.

Subjects and Method: This was a case control study carried out at Arifin Achmad Public Hospital in Riau. A sample of 80 study subjects was selected for this study, consisting of 40 subjects with hypertension and 40 subjects without hypertension. The dependent variable was hypertension. The independent variables were sodium and fat intake. Food intake was measured by Food Frequency Questionary (FFQ). Odds ratio was used to measure association.

Results: Hypertension was associated with high sodium intake $(\mathrm{OR}=2.81 ; 95 \% \mathrm{CI}=$ 1.13 to $6.99 ; \mathrm{p}=0.025)$ and high fat intake $(\mathrm{OR}=2.51 ; 95 \% \mathrm{CI}=1.19$ to $6.19 ; \mathrm{p}=0.044)$. Conclusion: Hypertension is associated with high sodium and fat intake.
\end{abstract}

Keywords: natrium, fat, hipertension

Correspondence:

Annisa Amalia Huzaipah. Faculty of Public Health, Universitas Sumatera Utara.

Email: annisaamaliahzp@gmail.com. Mobile Phone: 0852-7829-6171

The $5^{\text {th }}$ International Conference on Public Health

Best Western Premier Hotel, Solo, Indonesia, February 13-14, $2019 \mid 58$

https://doi.org/10.26911/theicph.2019.01.04 